\title{
PEMBELAJARAN KETERAMPILAN BERBICARA BAHASA ARAB MELALUI PENDEKATAN KOMUNKATIF
}

\author{
Muspika Hendri \\ Universitas Islam Negeri Sultan Syarif Kasim Riau \\ Email: muspikahendri@gmail.com
}

\begin{abstract}
This article describes the Arabic learning in terms of speaking skills using communicative approach. In Arabic language learning is known four language skills that must be possessed by students that are listening skills (maharah al-istima '), speaking skill (maharah al-kalam), reading skill (maharah al-qira ah), writing skill (maharah al-kitabah). To obtain language skills in the learning process and become a daily habit in the environment would require the competence of Arabic teachers who have an innovative approach in teaching. One of the approaches of learning speaking skills is by using a communicative approach. The steps are (1) the learner hears, reads, then practices a two-line dialogue with his partner, (2) hears and repeats it, (3) listens to the dialogue model and then repeats it by observing the names in the dialog with their own name, (4) ) read the question hint and make a question, (5) read a two-line dialogue framework then practice with his partner, (6) hear reading the question model and ask.
\end{abstract}

Keywords : learning, speaking skill, communicative approach

\section{A. Pendahuluan}

Bahasa Arab mempunyai peranan penting dalam pergaulan manusia dewasa ini yang telah memasuki dunia globalisasi informasi dan komunikasi. Oleh karena itu jelaslah sudah kepentingan mempelajari bahasa Arab bukan saja untuk keagamaan tetapi juga untuk pergaulan antar sesama bahkan antar bangsa. Bahasa Arab telah diakui PBB secara resmi sebagai bahasa Internasional pada tahun 1973. Ini membuktikan bahwa bahasa Arab berperan penting sebagai alat komunikasi ditingkat internasional. Bahasa Arab semakin menarik untuk dipelajari bukan dari dorongan keagamaan semata tetapi juga dilatarbelakangi oleh perdagangan, politik, dan pendidikan. ${ }^{1}$ Oleh karena itu, dari aspek pendidikan memperlajari bahasa Arab sangatlah penting melalui strategi,

\footnotetext{
${ }^{1}$ Abdullah Mu'in, Analisis Kontrastif Bahasa Arab dan Bahasa Indonesia, (Jakarta: Al-Husna Baru, 2004), hlm. 40
} 
metode yang lebih inovatif dan kreatif agar keterampilan bahasa yang dicapai bisa terwujud dengan nyata terutama kemampuan dalam bidang komunikasi bahasa Arab.

Ada tiga kompetensi yang hendak dicapai dalam pembelajaran bahasa Arab: pertama, kompetensi kebahasaan maksudnya adalah pembelajar menguasai baik secara membedakannya dan pengucapannya, mengenal struktur bahasa, gramatika dasar aspek teori dan fungsi mengetahui kosa kata dan penggunaaannya. Kedua, kompetensi komunikasi maksudnya adalah pembelajar mampu menggunakan bahasa Arab secara otomatis mengungkap ide-ide dan pengalaman dengan lancar, dan mampu menyerap yang telah dikuasai dari bahasa secara mudah. Ketiga, kompetensi budaya, maksudnya adalah memahami apa yang terkandung dalam bahasa Arab dari aspek budaya mampu mengungkapkan tentang pemikiran penuturnya, nilai-nilai, adat istiadat, etika dan seni. ${ }^{2}$

Stigma yang berkembang di siswa sekolah umum maupun sekolah agama bahwa mempelajari bahasa Arab dianggap rumit dan sulit karena bisa jadi guru yang mengajar salah langkah dalam menerapkan strategi dan metode dalam pembelajaran bahasa Arab. Seperti siswa dianjurkan menghafal banyak kosa kata (mufradat) setiap hari, atau lebih banyak penekanan pada tata bahasa dan tidak kontekstual sehingga kemampuan siswa dalam berbicara dan berkomunikasi sesama teman tidak tercapai, padahal setiap bahasa memiliki tingkat kesulitan dan kemudahan yang berbeda tergantung pada karakter system bahasa itu sendiri.

Dalam pembelajaran bahasa Arab dikenal empat keterampilan berbahasa yang harus dimiliki siswa yaitu: keterampilan mendengar (maharah al-istima'), keterampilan berbicara (maharah al-kalam), keterampilan membaca (maharah al-qira`ah), keterampilan menulis (maharah al-kitabah), dalam penguasaan empat keterampilan berbahasa tersebut, sebagian ahli bahasa berasumsi bahwa kemampuan kebahasaan seseorang hanya ditentukan oleh tingkat penguasaan terhadap kosa kata. ${ }^{3}$ Ini tentu relevan dengan keterampilan berbahasa sebagai alat komunikasi harus terlebih dahulu harus menguasai kosa kata (mufradat). Setiap pemebelaajran bahasa Arab tidak akan lepas dari metode, strategi, maupun media.

\footnotetext{
${ }^{2}$ Abdurrahman al-Fauzan, et.al., Durus al-Daurat al-Tadribiyah li al-Mu'allim al-Lughah al'Arabiyah li Ghairi Nathiqin Biha, (t.t.: Mu'assasah al-Waqf al-Islami, 1425 H.), hlm. 27

${ }^{3}$ Syaiful Mustofa, Startegi Pembelajaran Bahasa Arab Inovatif, (Malang: UIN Malik Press, 2011), hlm. 2
} 
Keterampilan berbicara dapat diperoleh dengan pembiasaan. Pembiasaan itu sendiri wujud pelaksanaannya latihan berulang kali dalam program revisi termasuk di dalamnya strategi dalam pembelajaran tersebut. Menurut teori Bloomfied (1887-1949) disinergikan dengan teori B. F. Skinner (1904-1990), bahwa pemerolehan bahasa itu mirip dengan pemerolehan kebiasaan lain. Bahasa dinilai sebagai bagian dari kebiasaan atau perilaku bahasa yang diperoleh atau dipelajari oleh anak kecil secara bertahap melalui istima', peniruan (taqlid), pengulangan (tikrar) hingga bahasa itu dikuasai dengan baik dan menjadi kebiasaan. ${ }^{4}$ Untuk memperoleh kecakapan berbahasa dalam proses pembelajaran dan menjadi kebiasaan sehari-hari dalam lingkungannya tentu memerlukan kompetensi guru bahasa Arab yang mempunyai strategi yang inovatif dalam mengajar.

Guru bahasa Arab sama halnya dengan guru mata pelajaran lainnya di sekolah harus memiliki kompetensi paedagogik, seperti penguasaan guru terhadap teori dan prinsip-prinsip pembelajran, mampu mengembangkan kurikulum yang berkaitan dengan mata pelajaran yang diasuh, menyelenggarakan pembelajaran yang mendidik, memanfaatkan tekhnologi dalam pembelajran dan lain sebagainya.

Dalam Peraturan Menteri Pendidikan Nasional tahun 2007 disebutkan bahwa kompetensi guru bahasa Arab adalah memiliki pengetahuan tentang berbagai aspek kebahasaan dalam bahasa Arab (linguistik, wacana, sosiolinguistik, dan strategis). Menguasai bahasa Arab lisan dan tulis, reseptif dan produktif dalam segala aspek komunikatifnya (linguistik, wacana, sosiolinguistik, dan strategis).

Memiliki pengetahuan tentang berbagai aspek kebahasaan dan strategi menunjukkan guru harus memiliki kemampuan kebahasaan atau kifayat al-lughawiyah dan kompetensi kemampuan dalam membelajarkan bahasa Arab atau kifayat thuruq alta'lim.

Kemampuan kebahasaan adalah kemampuan guru dari aspek penguasaan materi baik itu yang berkaitan dengan kemahiran berbahasa seperti maharah al-istima', muhadatsah, qira`ah, dan kitabah. Penguasaan yang berkaitan dengan unsur-unsur kebahasaan seperi kemampuan dalam hal qawaid (gramatika) ilm al-ashwat (fonem), morfologi dan ilmu dilalah (sintaksis). Adapun kemampuan dalam hal kifayah thuruq al-ta'lim adalah kemampuan guru dalam proses pelaksanaan pembelajaran seperti

\footnotetext{
${ }^{4}$ Anas Muhammad Ahmad Qasim, Muqaddimah fi Sikulujiyah al-Lughah, (Beirut: Markaz alIskandariyah li al-Kitab, 2000), hlm. 54-55
} 
menentukan pendekatan dalam pembelajaran, memilih strategi pembelajaran, metode dan lain sebagainya yang keseluruhan kemampuan ini tergambar dalam kompetensi profesionalisme paedagogik seorang guru bahasa Arab.

Strategi pembelajaran adalah cara-cara yang akan digunakan oleh pengajar untuk memilih kegiatan belajar yang akan digunakan selama proses pembelajaran. Pemilihan tersebut dilakukan dengan mempertimbangkan situasi dan kondisi yang ada, sumber belajar, kebutuhan siswa dan karakteristik siswa yang dihadapi dalam rangka mencapai tujuan pembelajaran. Sedangkan strategi pembelajaran atau disebut dengan teknik pengajaran adalah operasional dari metode. Karena itu teknik pengajaran berupa rencana, aturan-aturan langkah-langkah serta sarana yang pada prakteknya akan diperankan dalam proses belajar mengajar di dalam kelas guna mencapai dan merealisasikan tujuan pembelajaran. ${ }^{5}$

Tugas utama seorang pengajar adalah menyelenggarakan kegiatan pembelajaran. Agar kegiatan itu terselenggara dengan efektif, seorang pengajar harus mengetahui hakikat kegiatan belajar mengajar dan strategi pembelajarannya. Belajar merupakan suatu proses perubahan tingkah laku melalui interaksi antara individu dan lingkungan di mana dia hidup. Dalam hal proses merupakan rangkaian kegiatan yang berkelanjutan, terencana, gradual, bergilir, berkeseimbangan dan terpadu, yang secara keseluruhan mewarnai dan memberikan karakteristik terahadap proses pembelajaran.

Untuk meningkatkan perkembangan pembelajaran bahasa Arab di lembaga pendidikan perlu adanya penciptaan strategi inovatif dari guru bahasa Arab agar tujuan pembelajaran bahasa Arab tercapai dengan baik. Khusus untuk pencapaian keterampilan berbicara tentu ini memerlukan latihan-latihan yang rutin agar siswa terbiasa dalam pola tingkah lakunya untuk selalu berbicara bahasa Arab sehingga bisa berkomunikasi antara sesama mereka dan terbentuklah bi ah lughawiyah di lembaga tersebut. Kemampuan berkomunikasi bahasa Arab merupakan tujuan pokok dalam berbahasa. Karena hakikat dari bahasa adalah ujaran atau berbicara. Ditambah lagi tuntutan dunia kerja sekarang ini orang harus mampu berkomunikasi bahasa asing salah satunya adalah bahasa Arab.

Dalam pencapaian tujuan pembelajaran bahasa Arab, maka strategi sangatlah penting untuk diterapkan di lembaga pendidikan apalagi di pondok pesantren, bahasa Arab salah satu mata pelajaran yang harus dikuasai oleh santri baik dalam bentuk lisan 4.

${ }^{5}$ M. Abdul Hamid, et.al., Pembelajaran Bahasa Arab, (Malang: UIN Malang Press 2008), hlm. 
maupun tulisan. Apalagi di pondok pesantren mempunyai peraturan tersendiri tentang penerapan bahasa Arab, yang mana seluruh santri wajib berkomunikasi pakai bahasa Arab tersebut. Istilah strategi yang diterapkan dalam dunia pendidikan, khususnya dalam kegiatan belajar mengajar adalah suatu seni dan ilmu untuk membawakan pengajaran di kelas sedemikian rupa menarik, sehingga tujuan yang telah ditetapkan dapat tercapai efektif dan efisien. ${ }^{6}$

Menurut Uno, strategi pembelajaran adalah suatu cara yang akan dipilih dan digunakan oleh seoarang pengajar untuk menyampaikan materi pembelajaran sehingga akan memudahkan siswa menerima dan memahami materi pembelajaran, yang pada akhirnya tujuan pembelajaran dapat dikuasainya di akhir kegiatan pembelajaran. ${ }^{7}$ Sedangkan komponen dari strategi pembelajaran meliputi: kegiatan pendahuluan, penyampaian informasi, partisipasi siswa, evaluasi, dan kegiatan lanjutan.

Prinsip-prinsip pembelajaran bahasa Arab ada lima prinsip yaitu: prioritas atau mendahulukan yang utama, ketepatan, tahapan, aspek motivasi, serta baku dan mendasar. $^{8}$

Adapun karakteristik bahasa Arab yang mencolok sebagaimana yang dikemukan oleh Fathi Ali Yunus, adalah: bahasanya isytiqaqiyah bahasanya banyak perubahan, struktur kalimatnya paling banyak, adanya fi'il dan wazan-wazannya, struktur kalimatnya tidak membutuhkan tubi. Dan juga cara menulis dan membacanya dari kanan ke kiri. ${ }^{9}$

Strategi pembelajaran bahasa Arab adalah serangkaian upaya yang dilakukan oleh guru bahasa Arab untuk membuat proses pembelajaran berjalan sesuai denagn konsep yang telah ditentukan. Konsep yang harus diciptakan oleh guru adalah pembelajaran yang efektif, komunikatif, efisien, menyenangkan, inovatif, gembiran dan berbobot.

\footnotetext{
${ }^{6}$ Gulo W., Strategi Belajar Mengajar, (Jakarta: Grapindo, 2002), hlm. 7

${ }^{7}$ Saiful Mustofa, loc.cit.

${ }^{8}$ Kamal Ibrahim Badri dan Mamduh Nur al-Dini, Usus Ta'lim al-Lughah al-Ajnabiyah li alDawarat al-Tarbiyah, (Jakarta: Mutsaqqafah, 1407 H.), hlm. 3

${ }^{9}$ Fathi 'Ali Yunus et.al., Asasiyat Ta'lim al-Lughah al-'Arabiyah wa al-Tarbiyah al-Diniyah, (Cairo: Dar al-Tsaqafah, 1981), hlm. 17-19
} 


\section{B. Keterampilan Berbicara}

Keterampilan berbicara merupakan salah satu jenis kemampuan berbahasa yang ingin dicapai dalam pengajaran bahasa Arab. Berbicara merupakan sarana untuk membina saling pengertian, komunikasi timbal balik, dengan menggunakan bahasa sebagai media. Kegitan berbicara ini sebenarnya merupakan kegiatan yang menarik dalam kelas. Akan tetapi sebaliknya kegaitan berbicara tidak menarik, tidak merangsang situasi, suasana menjadi kaku dan akhirnya macet. Namun demimkian semuanya ini tergantung pada pengajar. Apabila pengajar dapat meransang situasi pembelajaran menjadi hidup, dan dapat memilih teknik yang sesuai dengan tingkatan kemampuan siswa serta memiliki kreativitas dala mengembangkan strategi pembelajaran tentu pemasalahn ini dapat diatasi dengan baik.

Faktor lain yang penting dalam menghidupkan kegiatan berbicara adalah keberanian murid dan perasaan tidak takut salah. Oleh karena itu pengajar dituntut mampu memberikan dorongan kepada siswa agar berani berbicara kendatipun dengan resiko salah. Kepada siswa hendaknhya ditekankan bahwa takut salah adalah kesalahan besar. Secara umum tujuan latihan berbicara bahasa Arab untuk tingkat pemula, tingkat menengah, dan tingkat lanjutan adalah agar siswa mampu berkomunikasi lisan secara baik dan benar dengan orang lain. Dalam memulia latihan berbicara, terlebih dahulu didasari oleh kemampun mendengarkan, kemampuan penguasaan kosa kata dan keberanian mengunkapkan apa yang ada dalam pikirannya. ${ }^{10}$

Keterampilan berbicara pada hakikatnya merupakan keterampilan memproduksi arus sistem bunyi artikulasi yang bertujuan untuk menyampaikan kehendak, kebutuhan perasaan dan keinginan pada orang lain. Pengertian keterampilan berbicara merupakan suatu keterampilan menyampaikan pesan secara lisan kepada orang lain. Penggunaan bahasa secara lisan dipengaruhi oleh berbagai faktor yang secara praktis bisa disimak pelafalan, intonasi, pilihan kata, struktur kata dan kalimat, sistematika pembicaraan, isi pembicaraan, cara memulai dan mengakhiri pembicaraan serta penampilan.

Tujuan dari pembelajaran keterampilan berbicara: pertama, kemudahan berbicara, peserta didik harus dapat kesempatan yang besar untuj berlatih berbicara sampai mereka mampu mengembangkan keterampilan berbicara secara lancar, dan

\footnotetext{
${ }^{10}$ Imam Makruf, Strategi Pembelajaran Bahasa Arab Aktif, (Jakarta: Needs Press, 2009), hlm. 6
} 
menyenangkan baik di dalam kelompok kecil maupun di hadapan pendengar umum. Para peserta didik perlu mengembangkan kepercayaan yang tumbuh melalui latihan.

Kedua, kejelasan, dalam hal ini peserta didik berbicara dengan tepat dan jelas baik artikulasi maupun diksi kalimat-kalimatnya. Gagasan yang diucapkan harus tersusun dengan baik. Agar kejelasan dalam berbicara tesebut bisa tercapai dengan baik. Ketiga, bertanggung jawab, latihan berbicara yang bagus menekankan pembicaraan untuk bertanggung jawab agar berbicara secara tepat, dan dipikirkan dengan sungguhsungguh mengenai topik yang akan dijadikan pembicaraan, tujuan pembicaraan, siapa yang diajak berbicara, dan bagaimana sitausi pembicaraan serta momentumnya pada saat itu.

Keempat, membentuk pendengaran yang kritis, latihan berbicara yang baik sekaligus mengembangkan keterampilan menyimak secara tepat dan kritis juga menjadi tujuan utama program pembelajaran ini. Disini peserta perlu belajar untuk dapat mengevaluasi kata-kata yang telah diucapkan.

Kelima, membentuk kebiasaan, kebiasaan berbicara bahasa Arab tidak dapat dicapai tanpa ada niat yang sungguh-sungguh dari peserta didik. Kebiasaan ini diwujudkan melalui interaksi dua orang atau atau lebih yang telah disepakati sebelumnya. Tidak harus dalam komunitas besar. Dalam menciptakan kebiasaan berbahasa Arab ini dibutuhkan komitmen, komitmen ini bisa dari diri sendiri berkembang menjadi kesepakatn dengan orang lain untuk berbahasa Arab secara terus menerus.

\section{Strategi Pembelajaran Kalam (Berbicara)}

Strategi yang dapat digunakan dalam pembelajaran keterampilan berbicara antara lain adalah: pertama, strategi langsung, strategi bertujuan untuk melatih siswa menceritakan apa yang dilihat dalam bahasa Arab baik lisan maupun tulisan. Media yang digunakan dapat berupa gambar baik yang diproyeksi maupun yang tidak diproyeksikan.

Kedua, strategi jigsaw, strategi ini biasanya digunakan dengan tujuan untuk memahami isi sebuah bacaan secara utuh dengan cara membagi-baginya menjadi beberapa bagian kecil. Masing-masing siswa memiliki tugas untuk memahami sebagian 
isi bacaan tersebut kemudian digabungkan menjadi satu. Dengan cara demikian isi bacaan yang panjang dapat dipahami secara tepat.

Ketiga, strategi group kecil, dalam strategi ini kelas dibagi menjadi beberapa kelompok kecil. Masing-masing kelompok akan melakukan tugas yang diberikan pengajar. Kemudian hasinya dipersentasekan di depan kelas. Sehingga masing-masing siswa akan merasakan pengalaman belajar bersama.

Keempat, strategi melihat gambar, penggunaan strategi ini di antaranya ditujukan untuk melatih kemampuan siswa dalam memahami isi sebuah bacaan kemudian mampu memvisualisasikannya dalam bentuk gambar. Dari gambar tersebjut diharapkan semua siswa dapat menghafal isi bacaan secara lebih mudah dan ingatan siswa terahdap isi bacaan tersebut dapat bertahan lebih lama.

Ada beberapa aspek yang perlu diperhatikan oleh pengajar dalam pembelajaran keterampilan berbicara antara lain:

1. Dalam melatih percakapan pengajar harus memberi contoh terlebih dahulu dengan intonasi dan ekspresi yang benar-benar menggambarkan pengertian secara tepat.

2. Dalam percakapan bebas hendaknya pengajar memberikan perhatian khusus kepada siswa yang pemalu, berikan dorongan kepada siswa untuk tampil berbicara.

3. Dalam mengikuti percakapan atau pembicaraan siswa, sebaiknya pengajar bersabar untuk tidak terburu-buru memberikan pembetulan setiap kali siswa berbuat kesalahan.

4. Susunan kelas hendaknya dirubah sedemikian rupa sehingga memungkinkan partisipasi seluruh anggota kelas dalam kegiatan pembelajaran.

5. Azaz pembelajaran keefektifan berbicara mencakup unsur-unsur kebahasaan dan non kebahasaan yang secara rinci dicantmkan dalam penilaian. ${ }^{11}$

\section{Konsep-konsep Dasar Komunikasi}

Kompetensi komunikatif merupakan kemampuan untuk menerapkan kaidah gramatikal suatu bahasa dalam membentuk kalimat-kalimat yang benar dan untuk mengetahui kapan, di mana, dan kepada siapa kalimat-kalimat itu diujarkan.dengan

\footnotetext{
${ }^{11}$ Syaiful Mustofa, op.cit., hlm. 153
} 
berbekal kompetensi komukatif seseorang dapat menyampaikan suatu pesan secara interpersonal dalam konteks spesifik. Krasehan juga menegaskan bahwa kompetensi komunikatif lebih menekankan kepada fungsi bahasa dalam komunikasi sesungguhnya dari pada menguasai bentuk dan kaidah kebahasaan.

Menurut Tarigan kompetensi komunikasi meliputi: pertama, pengetahuan mengenai tata bahasa dan kosakata bahasa yang bersangkutan; kedua, pengetahuan mengenai kaida-kaidah berbicara yaitu bagaimana cara memulai dan mengakhiri percakapan; ketiga, mengetahui bagaimana cara menggunakan dan memberi respon terhadap berbagai tipe dan tindak tutur seperti meminta, memohon dan mengundang orang; keempat, mengehatui bagaimana cara menggunakan bahasa secara tepat dan memuaskan. $^{12}$

Pada dasarnya pendekatan komunikatif ini merupakan pendekatan pembelajaran bahasa yang lebih menekankan yang lebih menekankan pembelajaran pada penguasaan kecakapan berbahasa dari pada penguasaan struktur bahasa.

\section{Asumsi-asumsi Pendekatan Komunikatif}

Yang menjadi asumsi-asumsi pendekatan komunikatif sebagaimana yang dikemukakan oleh Ahmad Fuad adalah:

a. Setiap manusia memiliki kemampuan bawaan yang disebut dengan language acquisition devide (LAD). Oleh karena itu kemampuan bahasa bersifat kreatif dan lebih ditentukan oleh faktor internal.

b. Penggunaan bahasa tidak hanya terdiri atas empat keterampilan tetapi mencakup beberapa kemampuan dalam kerangka komunikatif yang luas sesuai dengan peran peserta, situasi dan tujuan interaksi.

c. Belajar bahasa kedua dan bahasa asing sama dengan belajar bahasa pertama, yaitu berangkat dari kebutuhan dan minat siswa.

Dari asumsi di atas dapat dikatakan bahwa dalam pembelajaran bahasa asing (Arab) pembelajar telah memiliki kemampuan bahasa yang bersifat kreatif yang bisa dibangkitkan dengan pendekatan internal yaitu memunculkan minat belajar bahasa Arab.

\section{2.}

${ }^{12}$ Henry Guntur Tarigan, Pengajaran Kompetensi Bahasa, (Bandung: Angkasa, 1990), hlm. 31- 


\section{Prinsip-prinsip Pendekatan Komunikatif}

a. Pembelajar akan belajar bahasa dengan baik bila ia diperlukan sebagai individu yang memiliki kebutuhan dan minat.

b. Pembelajar akan belajar bahasa dengan baik bila ia diberikan kesempatan untuk berpartisipasi dalam penggunaan bahasa sasaran secara komunikatif dalam berbagai macam aktivitas.

c. Pembelajar akan belajar bahasa dengan baik bila ia dipajangkan ke dalam data komunikatif yang bisa dipahami dan relevan dengan kebutuhan dan minat.

d. Pembelajar akan belajar bahasa dengan baik bila ia secara sengaja memfokuskan pembelajarannya kepada bentuk keterampilan, dan strategi untuk mendukung proses pemerolehan bahasa.

e. Pembelajar akan belajar bahasa dengan baik bila ia dibeberkan dalam data sosiokultural dan pengalaman langsung dengan budaya menjadi bagian dari bahasa sasaran.

f. Pembelajar akan belajar bahasa dengan baik bila ia menyadari akan peran dan hakikat bahasa dan budaya.

g. Pembelajar akan belajar bahasa dengan baik bila ia diberi umpan balik yang tepat yang menyangkut kemajuan mereka.

h. Pembelajar akan belajar bahasa dengan baik bila ia diberi kesempatan untuk mengatur pembelajaran mereke sendiri. ${ }^{13}$

\section{Ciri-ciri Pendekatan Komunikatif}

Adapun ciri-ciri pelaksanaan pendekatan komunikatif sebagaimana yang disebut oleh Finochiaro dan Brumfit (1983) adalah sebagai berikut:

a. Makna sangat penting.

b. Dialog bila digunakan.

c. Kontekstualitas merupakan pernyataan dasar.

d. Belajara bahasa berarti belajar komunikasi.

e. Komunikasi efektif diupayakan.

f. Pengulangan bisa dipakai, tetapi tidak sentral.

g. Pengucapan yang bisa dipahami.

h. Cara apapun yang bisa membantu pelajar menerima.

${ }^{13}$ Ahmad Muradi, Pembelajaran Menulis Bahasa Arab dalam Perspektif Komunikatif, (Jakarta: Prenada Media Group, 2005), hlm. 33 
i. Usaha untuk berkomunikasi bisa didorong dari awal.

j. Penggunaan bahasa ibu yang bijaksana jika dibutuhkan.

k. Penerjemahan bisa digunakan bila bermanfaat bagi pelajar.

1. Membaca dan menulis bisa dimulai sejak hari pertama.

m. Sistem linguistik dipelajari untuk berkomunikasi.

n. Kompetensi komunikasi adalah tujuan yang diinginkan.

o. Variasi bahasa merupakan konsep sentral dalam baha ajar dan metodologi.

p. Urutan ditentukan oleh pertimbangan isi, fungsi, atau makna yang mengikat minat.

q. Guru membantu pembelajar dengan cara apapun dan memotivasi mereka mempelajari bahasa.

r. Bahasa diciptakan oleh individu yang sering mencoba dan meralat.

s. Kefasihan bahasa yang bisa dipahami.

t. Pembelajar diaharapkan berinteraksi dengan orang lain.

u. Guru tidak mengetahui secara pasti bahasa apa yang akan digunakan pembelaja.

\section{E. Desain Pengajaran Bahasa Komunikatif}

\section{Tujuan Pengajaran}

Tujuan pengajaran bahasa komunikatif pada dasarnya ingin mengantarkan siswa menuju pencapaian kemampuan berbahasa dalam berbagai situasi. Azies dan Alwasilah menegaskan bahwa tujuan khusus pengajaran bahasa komunikatif bergantung pada kebutuhan si pembelajar. Dalam kurikulum tujuan pengajaran biasanya mencerminkan aspek tertentu dari komptensi komunikatif yang sesuai dengan tingkat kemahiran dan kebutuhan komunikatif pembelajar. ${ }^{14}$

\section{Silabus}

Pendekatan komunikatif merupakan istilah yang merujuk kepada rancang bangun silabus. Dalam pemebelajaran bahasa terdapat minimal tiga macam silabus dalam pendekatan komunikatif, yaitu:

a. Silabus fungsional-nasional yang merupakan komunikatif murni yang diarahkan langsung kepada pengembangan keterampilan komunikatif.

\footnotetext{
${ }^{14}$ Ibid., hlm. 41
} 
b. Silabus nasional, yang berorientasi pada semantic-gramatikal yang dikembangkan untuk mengatasi kelemahan -kelemahan silabus struktur.

c. Silabus situasional yaitu tata bahasa dan fungsi disusun saling berkaitan dan saling bergantung.

\section{Aktivitas Belajar Mengajar}

Aktivitas belajar mengajar pada pendekatan komunikatif menekankan pada pembinaan dan pengembangan kompetensi komunikatif. mengungkapkan bahwa hanya aktivitas-aktivitas yang menunjukkan komunikasi yang realistis yang mendorong pelajar untuk belajar dan aktivitas-aktivitas berbahasa yang bertujuan untuk memberikan tugastugas bermakna yang mendorong siswa untuk belajar.

\section{Peran Siswa, Guru, dan Bahan Ajar}

a. Peran Siswa

Peran siswa sebagai negasiator antara dirinya, proses belajar, dan objek pembelajaran muncul dari dan berinteraksi dengan peran negasiator bersama dalam kelompok dan di dalam prosedur dan aktivitas kelas yang dijalani kelompok. Implikasi bagi siswa adalah bahwa ia harus menyumbangkan sebisa mungkin dari yang ia peroleh, dengan demikian ia belajar secara bebas.

b. Peran guru

Dalam pembelajaran bahasa komunikatif guru berperan sebagai fasilitator. Sebagai individu yang mengetahui arah pengajaran, guru berperan dan mengkoordinasi kegaiatan siswa. Dengan demkian kegiatan itu betul-betul secara efisien mengarah kepada pengembangan kemampuan komunkatif.

c. Bahan Ajar

Bahan ajar harus diambil dari sampel bahan yang autentik, yaitu sampel yang diambil dari penggunaan bahasa dalam konteks komunikasi sesungguhnya. Tidak ada satu buku teks yang diwajibkan atau dianjurkan. Buku teks rekaman kaset, atau apapun yang dapat membantu mencapai tujuan langsung proses belajar mengajar dapat digunakan.

\section{F. Pendekatan Komunikatif pada Keterampilan Berbicara}

Persoalan-persoalan bagaimana menerapkan prinsip-prinsip pengajaran bahasa komunikatif pada tataran prosedur pengajaran di kelas masih menjadi pusat 
perbincangan. Pendapat para ahli mengisyaratkan bahwa prosedur-prosedur standar pengajaran bahasa komunikatif belum ada. Adanya berbagai model silabus pengajaran bahasa komunikatif membuktikan bahwa interprestasi para ahli terahadap pendekatan komunikatif berbeda-beda.

Prosedur pengajaran bahasa komunikatif yang dimaksud dalam tulisan ini adalah sebagai berikut:

1. Penyajian dialog singkat yang didahului pembangkitan motivasi siswa yang berkaitan dengan situasi.

2. Pelatihan oral, baik terhadap kelompok maupun individu.

3. Tanya jawab berkaitan dengan topik dan situasi dialog.

4. Tanya jawab tentang pengalaman pribada siswa berkaitan dengan dialog.

5. Membahas salah satu ungkapan atas struktur dan bisa memberikan tambahantambahan dari luar dari bentuk dialog singkat.

6. Penemuan dan merealisasikan kaidah-kaidah yang mendasari ungkapan fungsioanl atau struktur oleh siswa.

7. Pengenalan lisan atau interpretatif.

8. Aktivitas produksi lisan.

9. Mengenali dialog singkat dalam modul.

10. Pemberian tugas tulis untuk pekerjaan rumah.

11. Evaluasi pembelajaran secara lisan.

Dengan demikian prosedur pengajaran berdasarkan pendekatan komunikatif masih bervariasi. Sementara ini prosedur yang banyak dilakukan dalam kegaitan pembelajaran di kelas adalah prosedur-prosedur tersebut.Dalam hal ini guru dapat memilih prosedur-prosedur yang cocok dalam pengajaran komunikatif.

Beberapa langkah pembelajaran berbicara dengan pendekatan komunikatif:

1. Pembelajar mendengar, membaca, kemudian berlatih sebuah dialog dua baris dengan pasangannya.

2. Mendengar dan mengulanginya.

3. Mendengarkan model dialog lalu mengulanginya dengan mengamati nama-nama dalam dialog dengan nama mereka sendiri.

4. Membaca petunjuk pertanyaan dan membuat pertanyaan.

5. Membaca kerangka dialog dua baris kemudian berlatih dengan pasangannya.

6. Mendengar membaca model pertanyaan dan bertanya. 


\section{G. Kesimpulan}

1. Dalam pembelajaran bahasa Arab dikenal empat keterampilan berbahasa yang harus dimiliki siswa yaitu : keterampilan mendengar (maharah al-istima'), keterampilan berbicara (maharah al-kalam), keterampilan membaca (maharah alqira'ah), keterampilan menulis (maharah al-kitabah). Dalam penguasaan empat keterampilan berbahasa tersebut, sebagian ahli bahasa berasumsi bahwa kemampuan kebahasaan seseorang hanya ditentukan oleh tingkat penguasaan terhadap kosa kata. Ini tentu relevan dengan keterampilan berbahasa sebagai alat komunikasi harus terlebih dahulu harus menguasai kosa kata (mufradat). Setiap pembelajaran bahasa Arab tidak akan lepas dari metode, strategi, pendekatan, maupun media. Keterampilan berbicara dapat diperoleh dengan pembiasaan. Pembiasaan itu sendiri wujud pelaksanaannya latihan berulang kali dalam program revisi termasuk di dalamnya strategi dalam pembelajaran tersebut. Menurut teori Bloomfied (1887-1949) disinergikan dengan teori B.F Skinner (1904-1990) bahwa pemerolehan bahasa itu mirip dengan pemerolehan kebiasaan lain. Bahasa dinilai sebagai bagian dari kebiasaan atau perilaku bahasa yang diperoleh atau dipelajari oleh anak kecil secara bertahap melalui istima', peniruan (taqlid), pengulangan (tikrar), hingga bahasa itu dikuasai dengan baik dan menjadi kebiasaan.

2. Untuk memperoleh kecakapan berbahasa dalam proses pembelajaran dan menjadi kebiasaan sehari-hari dalam lingkungannya memerlukan kompetensi guru bahasa Arab yang mempunyai strategi yang inovatif dalam mengajar. Strategi yang dapat digunakan dalam pembelajaran keterampilan berbicara antara lain adalah strategi langsung, strategi jigsaw, strategi group kecil, dan strategi melihat gambar.

3. Yang menjadi asumsi-asumsi pendekatan komunikatif sebagaimana yang dikemukakan oleh Ahmad Fuad adalah: pertama, setiap manusia memiliki kemampuan bawaan yang disebut dengan language acquisition devide (LAD). Oleh karena itu kemampuan bahasa bersifat kreatif dan lebih ditentukan oleh faktor internal. Kedua, penggunaan bahasa tidak hanya terdiri atas empat keterampilan tetapi mencakup beberapa kemampuan dalam kerangka komunikatif yang luas sesuai dengan peran peserta, situasi dan tujuan interaksi. Ketiga, belajar 
bahasa kedua dan bahasa asing sama dengan belajar bahasa pertama, yaitu berangkat dari kebutuhan dan minat siswa.

4. Langkah-langkah pembelajaran berbicara dengan pendekatan komunikatif:

a. Pembelajar mendengar, membaca, kemudian berlatih sebuah dialog dua baris dengan pasangannya.

b. Mendengar dan mengulanginya.

c. Mendengarkan model dialog lalu mengulanginya dengan mengamati namanama dalam dialog dengan nama mereka sendiri.

d. Membaca petunjuk pertanyaan dan membuat pertanyaan.

e. Membaca kerangka dialog dua baris kemudian berlatih dengan pasangannya.

f. Mendengar membaca model pertanyaan dan bertanya.

\section{H. Daftar Pustaka}

Abdullah Mu'in, Analisis Kontrastif Bahasa Arab dan Bahasa Indonesia, Jakarta: AlHusna Baru, 2004

Abdurrahman al-Fauzan, et.al., Durus al-Daurat al-Tadribiyah li al-Mu'allim alLughah al- 'Arabiyah li Ghairi Nathiqin Biha, t.t.: Mu'assasah al-Waqf al-Islami, $1425 \mathrm{H}$.

Ahmad Muradi, Pembelajaran Menulis Bahasa Arab dalam Perspektif Komunikatif, Jakarta: Prenada Media Group, 2005

Anas Muhammad Ahmad Qasim, Muqaddimah fi Sikulujiyah al-Lughah, Beirut: Markaz al-Iskandariyah li al-Kitab, 2000

Fathi 'Ali Yunus et.al., Asasiyat Ta'lim al-Lughah al-'Arabiyah wa al-Tarbiyah alDiniyah, Cairo: Dar al-Tsaqafah, 1981

Gulo W., Strategi Belajar Mengajar, Jakarta: Grapindo, 2002

Henry Guntur Tarigan, Pengajaran Kompetensi Bahasa, Bandung: Angkasa, 1990

Imam Makruf, Strategi Pembelajaran Bahasa Arab Aktif, Jakarta: Needs Press, 2009

Kamal Ibrahim Badri dan Mamduh Nur al-Dini, Usus Ta'lim al-Lughah al-Ajnabiyah li al-Dawarat al-Tarbiyah, Jakarta: Mutsaqqafah, $1407 \mathrm{H}$.

M. Abdul Hamid, et.al., Pembelajaran Bahasa Arab, Malang: UIN Malang Press 2008

Syaiful Mustofa, Startegi Pembelajaran Bahasa Arab Inovatif, Malang: UIN Malik Press, 2011 